\title{
Review Pergeseran Fotografi Dari Sistem Konvensional ke Digital (Virtual Photoshoot) Pada Masa Pandemi COVID-19
}

\author{
Adrian P Zen ${ }^{1 *}$, Dyah AW Sintowoko², lqbal P Wiguna ${ }^{3}$, \\ Arfi Andrian ${ }^{4}$, Gregorius KH Ginting ${ }^{5}$ \\ 1,2,3,4,5Department of Visual Art, Faculty of Creative Industries, \\ Telkom University, Bandung, Indonesia
}

\begin{abstract}
Virtual photoshoot is a new method in the development era of modern contemporary photography that was born due to the impact of COVID-19. This study finally tries to analyze the trend of virtual photoshoots as the use of photography technology during the Covid-19 pandemic. Virtual photoshoot is a development of photography. The method used in this research is a phenomenological approach regarding the use of online video call software in the process of shooting the object. The sample of this research is the photographic works of virtual photoshoot by Michael Fabians Cools when taking pictures using the sophisticated video call application. The results showed three main results, namely media, technical and aesthetic. In terms of media, research has found that the existence of social media such as Instagram can support the existence of a virtual photoshoot trend. Technically research, this virtual photoshoot implementation method is something new and has never happened before. The virtual photoshoot implementation method is applied in in-game screenshots and Google Street View, where virtual photoshoots offer a shooting process by taking pictures through an LCD monitor using video call software such as Zoom, Facetime, and Google Meet to bring up photo objects. Aesthetically, this study found that the results of photos from virtual photoshoots led to photography techniques that were not widely used before in conventional shooting, namely displaying the blur effect on photos using glasses or bottles. The blur effect that is usually produced through lens settings can also be produced with a glass or bottle.
\end{abstract}

\section{Keywords}

COVID-19, virtual photoshoot, development of photography, trend 


\section{Review Pergeseran Fotografi Dari Sistem Konvensional ke Digital (Virtual Photoshoot) Pada Masa Pandemi COVID-19}

Adrian P Zen, Dyah AW Sintowoko, Iqbal P Wiguna, Arfi Andrian, Gregorius KH Ginting

\section{PENDAHULUAN}

Fotografi bukanlah sebuah aktifitas yang baru bagi kebanyakan orang. Perkembangan teknologi tentang foto dapat ditemukan sangat mudah saat ini, seperti di smartphone ataupun kamera DSLR. Selain sebagai alat komunikasi, smartphone juga tampak multifungsi. Artinya, smartphone tidak hanya digunakan untuk menghasilkan still picture namun juga moving picture dimana kedua media tersebut dapat digunakan sebagai hasil karya foto. Foto-foto tersebut pada akhirnya banyak disebarkan melalui sosial media seperti Instagram dan Facebook. Tahap perkembangan ini berefek pada munculnya era fotografi baru dimana esksistensi Instagram dapat dilihat dari tingginya shared photo oleh anak muda sebagai media promosi ataupun media informasi [1].

Dalam dunia fotografi, terdapat tren foto dengan menggunakan smartphone. Trend tersebut merupakan sebuah rekayasa digital dimana penggunaan filter dan pengaturan edit mampu, melahirkan perkembangan tren fotografi baru yang lebih fleksibel dan masih diterapkan oleh pekerjaan professional di bidang fotografi. Trend fotografi tersebut yaitu berupa kehadiran fitur canggih dalam smartphone dimana hasil fotonya tampak setara dengan kualitas dari kamera DSLR ataupun Mirrorless. Tidak berhenti disitu, dari segi, kualitas gambar, resolusi, dan kecepatan pengaturan fokus objek fotografi, kualitas smartphone juga tidak kalah dengan advanced technology fotografi seperti DSLR.Memasuki tahun 2020, pada tanggal 30 Januari 2020, WHO secara resmi mendeklarasikan penyakit COVID 19 ini sebagai pandemic [2], dimana masyarakat disarankan untuk melakukan social distancing. Aturan tersebut berdampak pada terhambatnya bisnis yang memerlukan interaksi antar sesama manusia, karena diwajibkan untuk WFH (Work From Home). Dari latar belakang tersebut, maka penelitian ini menganalisis tentang bagaimana pergeseran dunia fotografi dari sistem konvensional menjadi digital (virtual shooting) terutama di masa pandemi ini.

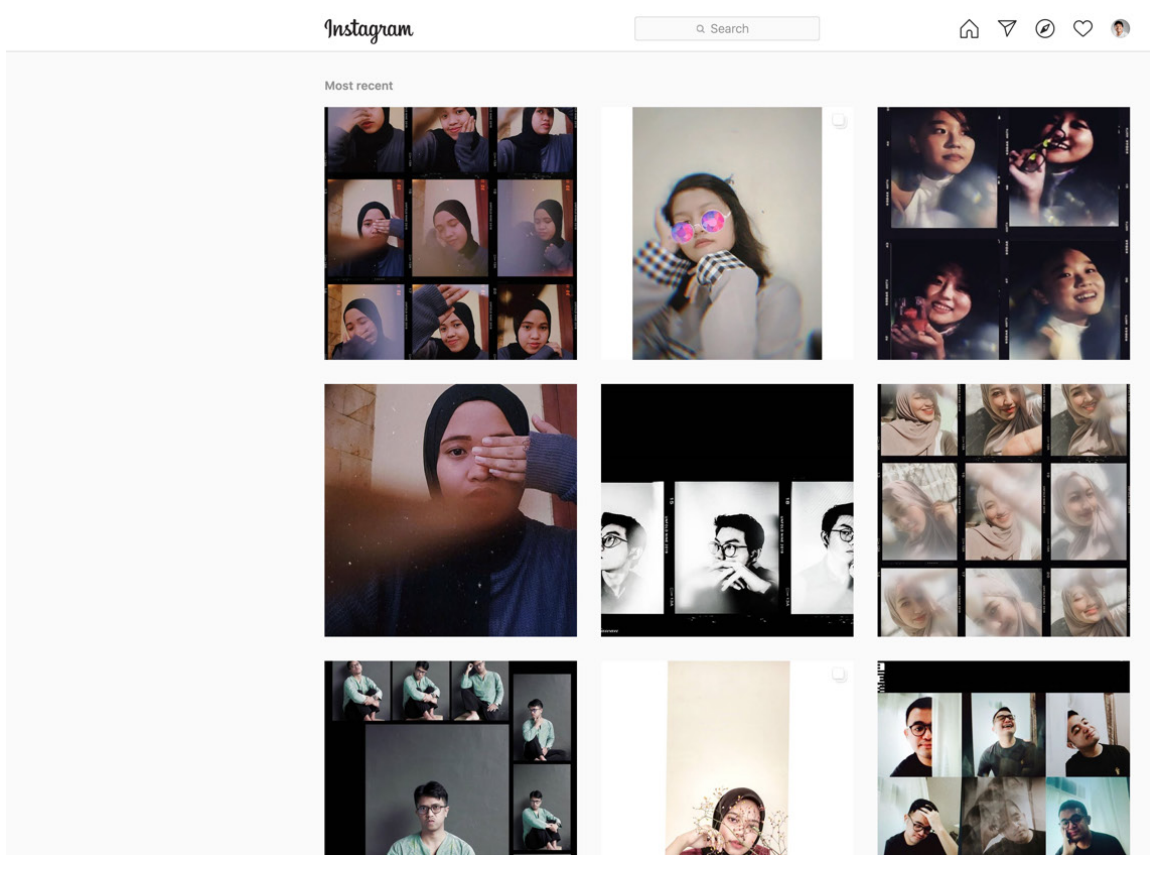

Gambar 1. Virtual 
Tren virtual shooting dimulai karena adanya pembatasan interaksi. Pembatasan interaksi ini membuat semua aktifitas dilakukan secara daring. Dimulai dari pembelajaran di sekolah, cara kerja online, membuat webinar, melakukan konferensi secara online, dan lainnya. Dengan penghambatan ini membuat hampir semua kegiatan cenderung menggunakan aplikasi berbasis software seperti Zoom, Google Meet, dan software lainnya. Software yang dipakai merupakan software untuk video call dimana pertemuan dapat dilakukan secara online dengan mempertemukan video dari masing masing anggota untuk bisa dilihat secara bersamaan. Dengan memanfaatkan teknologi ini, virtual photoshoot dapat digunakan.

Oleh sebab itu, dengan adanya perkembangan tren tersebut, rumusan masalah pada penelitian ini adalah apakah dengan tren virtual photoshoot dapat mengubah perkembangan fotografi dari sistem konvensional menjadi digital (serba virtual)? Bagaimana unsur estetika pada foto yang dihasilkan?

\section{METODE PENELITIAN}

Berdasarkan latar belakang yang telah disampaikan diatas, maka metode penelitian yang digunakan dalam penelitian ini adalah metode penelitian deskriptif kualitatif dengan pendekatan fenomenologi tentang virtual photoshoot. Data dikumpulkan dengan cara menguraikan secara eksploratif terhadap sampel yaitu karya fotografi yang sudah ada seperti karya fotografer.

\section{PEMBAHASAN}

\section{Media Instagram}

Perkembangan media sosial sekarang digunakan oleh manusia untuk melakukan aktifitas digital dengan membagikan hasil foto/video. Dengan adanya aktifitas tersebut insatgram sering dijadikan sebagai medium untuk promosi terutama dalam periklanan, sehingga menjadikan Instagram sebagai salah satu platform terbaik untuk marketing. Dengan perkembangan tersebut kepopuleran Instagram mulai naik dan makin menyebarkan aplikasinya. Instagram merupakan salah satu media "album terbuka" dimana semua orang dapat menyaksikannya dan dibuka secara luas. Berbagai kalangan membagikan hasil kreasinya berupa foto/video yang meliputi info berita, teknik fotografi, karya, foto makanan, ataupun produk yang ditawarkan sebagai media promosi sehingga menjadikannya sebagai platform untuk bersaing dengan membuat feed yang menarik.

Sosial media merupakan suatu hal yang unik, karena memungkinkan pengguna untuk mengartikulasikan dan membuat orang lain melihat jaringan sosial mereka. Hal ini dapat mengakibatkan realistisnya hubungan antar individu dan mampu mendorong hubungan laten di dunia offline [3]. Dengan perkembangan tersebut maka Instagram secara tidak lansung diikuti oleh munculnya gaya hidup yang baru serta tren-tren yang sedang terjadi di masyarakat, dimulai dari sebuah unggahan yang viral yang kemudia memunculkan gaya hidup baru. Dalam kata lain, gaya hidup baru diakibatkan oleh adanya dinamisme unggahan foto/video dalam Instagram [4]. Dalam perkembangan tren pada masa pandemic ini adalah tren virtual photoshoot.

\section{Virtual Photoshoot}

Virtual photoshoot atau Long Distance Photoshoot adalah aktifitas pemotretan dengan posisi objek / model dan fotografer terpisah dan tidak berada di satu tempat yang sama. Virtual photoshoot merupakan metode fotografi baru karena adanya perdebatan pada media baru, studi sains, dan teknologi, dan bidang terkait fotografi [5]. Medium tersebut berupa virtual photoshoot yang berisi tentang software video call dimana interaksi antara fotografer dan model dapat dilakukan. Software menjadi peranan yang signifikan dalam melakukan proses virtual photoshoot dikarenakan software lah yang menentukan hasil pada photoshoot dan memberikan intruksi pose dan pengaturan properti pada pemotretan. Pada saat mengambil foto fotografer mengambil gambar tersebut melalui layar LCD pada monitor dan mengambilnya menggunakan kamera. Maka dari itu, fotografer membuat foto masih tetap menggunakan kamera. Secara definisi fotografi, virtual photoshoot masih bisa dibilang fotografi karena masih tetap mengambil gambar dari kamera, yang membedakannya hanyalah objek yang ditangkapnya tidak dalam bentuk nyata tetapi dalam bentuk gambaran virtual pada LCD.

Virtual photoshoot juga dilakukan oleh fotografer lainnya. Seperti contohnya Alessio Albi, seorang fotografer yang berasal dari Italia yang memulai tren virtual photoshoot, menurut Allwyn Antony, fotografer dari Bengaluru yang dikutipnya dari Times of India [6, 7]. Sejak bulan Maret 2020, dia sudah memulai sesi pemotretan virtual melalui layar laptopnya.

Tren tersebut juga dilanjutkan di Indonesia. Ervina Claudia di kanal youtube dari Gleen Prasetya menjelaskan tentang tren virtual photoshoot yang dimulai oleh Michael Fabian Cools. Michael dianggap memulai tren fotografi ini dimana Raisa dijadikan sebagai model utama. Gambar 2 menggambarkan 
tentang bagaimana proses pemotretan dengan mengambil gambar melalui LCD monitor dengan menggunakan software video call zoom untuk berinteraksi dan memunculkan objeknya [6].

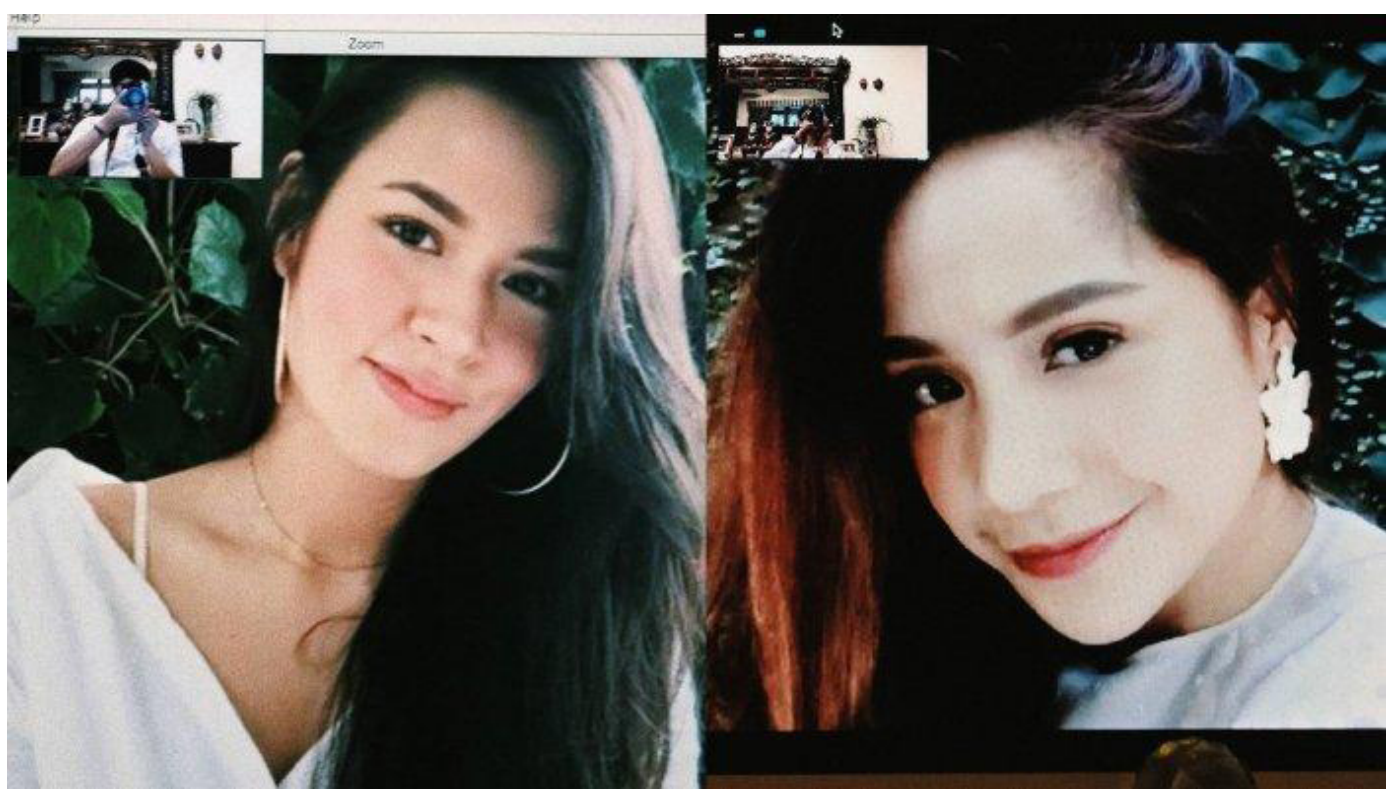

Gambar 2. Proses virtual photoshoot Raisa dan Nagita Slavina

(Sumber: https://solo.tribunnews.com/2020/05/20/nagita-slavina-raisa-hingga-adinia-wirasti-jadi-modelvirtual-photoshoot-intip-hasil-foto-fotonya?page=3)

Sebelumnya, istilah virtual photoshoot digunakan seperti pemotretan dalam dunia virtual. Hal ini biasanya terdapat pada game yang sifatnya open world games dalam arti dunia virtual yang luas.

Secara teknis, dalam sebuah game, pemotretan dapat dilakukan metode "screenshoot" pada layar yang kemudian dapat diatur mengenai sudut pandang, pencahayaan (lighting), serta shutter speed dan aperture [7]. Dalam hal ini kondisi pencahayaan dalam game tidak berubah dari waktu ke waktu karena pada dasarnya tetaplah sebuah software yang mengendalikan semuanya. Selain dalam game, fotografer yang menggunakan istilah virtual photoshoot dengan melakukan pemotretan virtual memanfaatkan Google Street View pada Google Maps. Salah satunya adalah karya fotografi dari Jackqui Kenny [8] yang menggunakan medium software Google.

Gambar 3. "ScapeMode" atau photo mode dalam game Gran Turismo Sport pada konsol Playstation 4.

(Sumber: https://www. engadget.com/2017-0804-gt-sport-scape-mode. $\mathrm{html})$

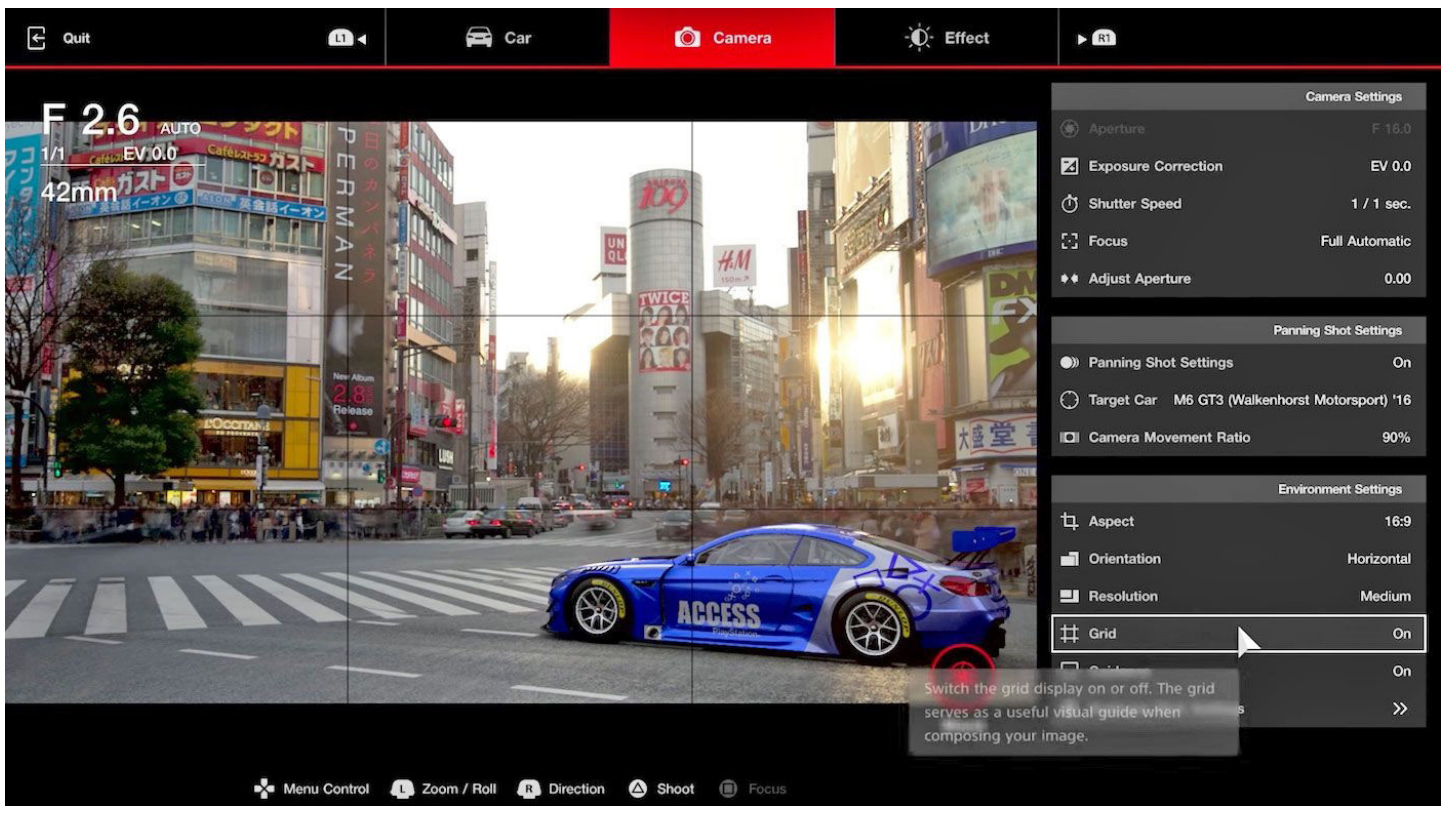

Pada tahun 2017, Google mempromosikan perangkat lunak tersebut dengan mencantumkan nama fotografer yang menggunakan metode ini. Ditandakan dengan tag "Meet the artist who photographed the world without leaving home" yang mengarah kepada website dari Jackui Kenny yang disebut dengan "The Agoraphrobic Traveler" dimana karya fotografi komposisi fotografi yang menarik dalam dunia virtual. 


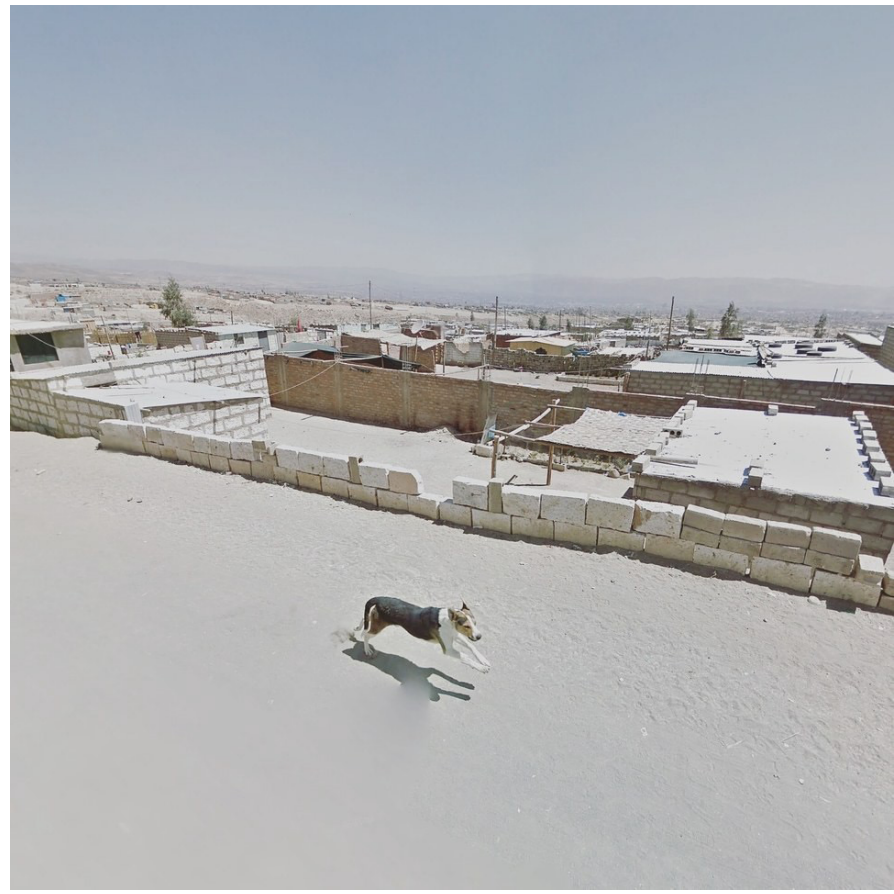

Gambar 4. Karya Jackuy

Kenny, fotografi virtual menggunakan aplikasi google street view dengan pendekatan street photography.

(Sumber: https://medium. com/@ACPfest/streetview-photographyfrom-doug-rickardthrough-jacqui-kenny5eb9b7a42df9)

Metode tersebut diberlakukan pada saat tidak ada pandemi seperti sekarang dan ketertarikan fotografer terhadap pemotretan virtual tidak banyak dilakukan. Hal ini dapat dilakukan oleh fotografer tersebut ingin mengambil pendekatan fotografi yang berbeda dari yang lainnya.

\section{Metode Pelaksanaan Virtual Photoshoot}

Satu perbedaan dari karya virtual photoshoot dalam dunia virtual ini adalah metodepengambilan gambar. Metode yang dilakukan oleh fotografer dalam virtual photoshoot pada Instagram dalam masa pandemi ini adalah menggunakan kamera yang memotret layer secara langsung. Adapun hasil bidikan layar akan sangat mempengaruhi fotografer dan model dari pengiriman data gambar. Adapun gambar tersebut adalah dari model yang hasilnya dapat ditampilkan pada layar fotografer. Selain koneksi internet yang digunakan, kualitas monitor yang dipakai oleh fotografer juga menentukan kualitas dari hasil foto yang dihasilkan.

Metode kedua yang bisa didapatkan adalah dengan metode screenshoot. Kelebihan dan kekurangan pada metode screenshoot dapat dilakukan dalam smartphone, laptop, maupun komputer untuk melakukan sesi pemotretan sebagai pengganti pemotretan lansung menggunakan kamera. Dalam prosesnya, pemotretan dibantu oleh aplikasi/software yang dapat melakukan video call secara lansung untuk memberikan arahan kepada model pada saat sesi pemotretan. Penggunaan aplikasi/software menjadi kunci untuk video call ini karena cukup berpengaruh karena server dari sebuah aplikasi/ software ini akan menentukan kualitas sinyal.

Banyak aplikasi yang menyediakan fitur video call live seperti LINE, Instagram, Whatsapp, Zoom, Google Meet, Facetime dan aplikasi lainnya. Faktor penentu pemilihan aplikasi ini adalah dari kualitas aplikasi itu sendiri dalam sektor kestabilan sinyal yang di berikan oleh aplikasi. Kebanyakan dari fotografer yang akan melakukan sesi pemotretan menggukan aplikasi dari Zoom dan Facetime karena kedua aplikasi itu memberikan kestabilan sinyal yang cukup kuat untuk melakukan video call. Kestabilan sinyal menentukan kelancaran dalam proses photoshoot. Sedangkan pada saat pemotretan pada umumnya, tidak dibatasi dengan faktor tersebut karena tidak melakukan video call. Pada umumnya fotografer dapat mengarahkan model dan melakukan pengaturan secara langsung.

\section{Kelebihan Dan Kekurangan}

Metode proses virtual photoshoot, mempunyai kekurangan dan kelebihan yang dapat dibedah.

Kelebihan metode Virtual Photoshoot:

1. Kecenderungan cahaya yang dipakai merupakan cahaya alami karena model cenderung tidak memiliki peralatan lighting studio. 
2. Tidak membutuhkan tim yang banyak dalam pengerjaanya dimana rata-rata dilakukan hanya dengan model dan fotografernya saja yang mekukan interaksi lewat media sosial.

Kekurangan metode Virtual Photoshoot:

1. Alat menjadi peranan penting dalam menentukan baik buruk nya sebuah foto. Jika alat yang digunakan tidak memiliki kualitas yang baik maka hasil foto akan mengikuti kualitas tersebut.

2. Pantulan cahaya dalam sebuah layar monitor dapat membuat pencahayaan pada kamera sedikit terganggu. Namun hal ini dapat diatasi dengan memainkan pemgaturan cahaya segitiga eksposure.

3. Koneksi internet yang stabil dan cepat untuk memperlancar proses pemotretan.

Proses yang dilakukan oleh fotografer sangat sederhana yakni, melakukan pemotretan dengan mengarahkan model pada layar, lalu editing foto dan mengirimkan balik kepada modelnya.

\section{Bahasan Estetika Virtual Photoshoot}

Secara estetika, virtual photoshoot mempunyai hasil foto yang unik dan berbeda dari yang lainnya. Jika dibandingkan dengan pemotretan pada umumnya, sebuah foto ditampilkan dengan tampilan yang jauh lebih tajam secara detail dan resolusi, sehingga hasil foto yang dihasilkan tidak terlihat pixelate. Jika dibandingkan dengan hasil foto pada virtual photoshoot, cenderung mempunyai hasil foto dengan efek blur untuk menutupi kekurangan dari foto.

Efek "blur" menjadi nilai estetis dalam virtual photoshoot ini. Blur tidak berupa efek yang sama seperti bokeh yang dihasilkan dari lensa, akan tetapi lebih mengarah kepada pembelokan cahaya yang dihasilkan oleh gelas. Gelas digunakan sebagai foreground pada foto untuk menghasilkan foto yang terlihat lebih berseni. Efek yang dihasilkan dari sebuah gelas atau botol bisa dimodifikasi sedemikian rupa seperti menambahkan air pada gelas untuk menghasilkan efek blur yang bervariasi. Bisa juga dengan menambahkan air yang berwarna sehingga menghasilkan portrait yang mempunyai keanekaragaman warna. Hal ini tergantung dari pola pikir kreatif dari fotografer untuk menutupi kekurangan pada ketajaman hasil foto.

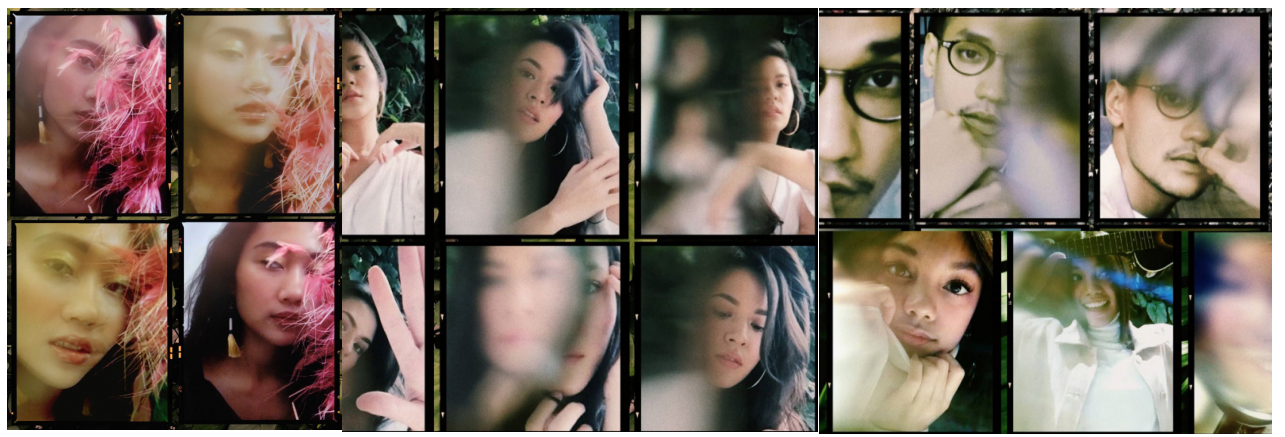

Gambar 5. Contoh hasil foto dengen efek "blur" menggunakan gelas/botol (Sumber: https://editorial. femaledaily.com/blog/2020/05/20/tips-virtual-photoshoot-dari-michael-cools/)

Hasil foto pada gambar 5 merupakan karya dari fotografer Indonesia Michael Fabian Cools yang mempromosikan karya fotonya dengan hashtag creative quarantine. Dengan mencoba untuk melakukan pemotretan menggunakan properti yang sering didapatkan dirumah seperti gelas, botol, bunga, dan lainnya untuk bisa mendapatkan hasil foto yang kreatif dan mempunyai efek foto yang lebih artistik. Efek ini dalam pemotretan fotografi dapat dilakukan menggunakan filter khusus atau filter DIY (Do It Yourself) yang dibuat sendiri oleh fotografernya sendiri.

Contoh lainnya adalah karya dari Laura Basuki yang mempunyai pendekatan fotografi yang berbeda. Dengan teknik virtual photoshoot pada umumnya, Laura Basuki dipotret menggunakan teknik seperti double exposure pada foto sehingga dakam satu frame terdiri dari dua objek yang digabungkan sehingga mendapatkan hasil pemotretan yang berbeda dari yang lain.

Hasil foto yang dihasilkan juga tidak terdiri dari satu hasil foto saja namun menghasilkan beberapa frame. Dalam satu frame pada Instagram, hanya satu foto untuk menghasilkan sebuah postingan pada feed di media sosial. Seiring dengan perkembangan aplikasi Instagram yang mengikuti tren-tren fotografi secara terus menerus, aplikasi Instagram terus berkembang dan mulai memperbolehkan satu feed untuk memposting beberapa slide foto. Hasilnya semua hasil foto dari virtual photoshoot diunggah secara bersamaan. Namun dengan hasil foto yang didapatkan, rata-rata cenderung mem- 


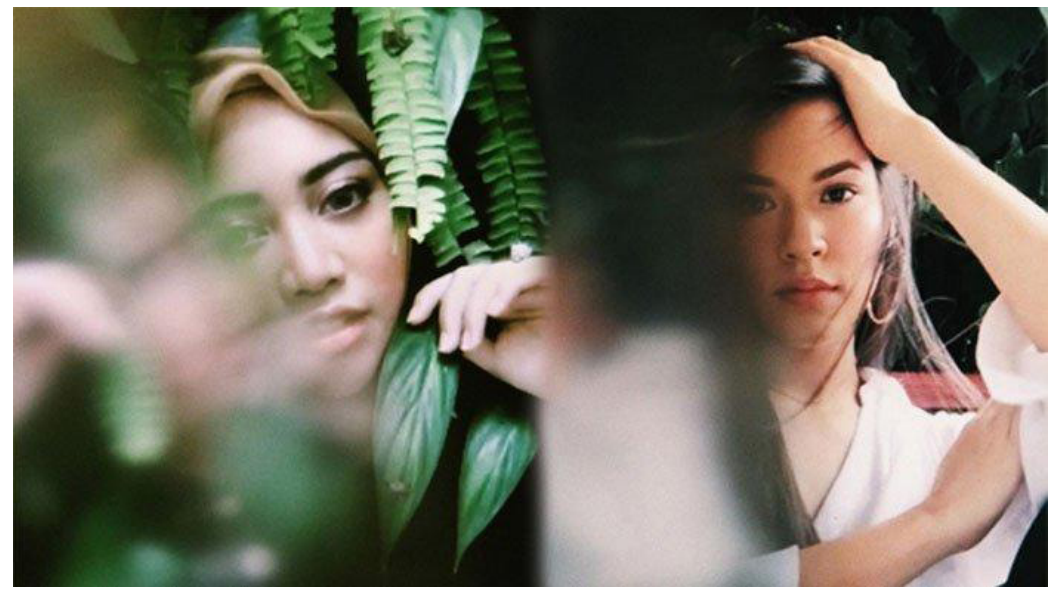

Gambar 6. Karya Jackuy Kenny, fotografi virtual menggunakan aplikasi google street view dengan pendekatan street photography.

(Sumber: https://medium com/@ACPfest/streetview-photographyfrom-doug-rickardthrough-jacqui-kenny5eb9b7a42df9)

posting hasil foto dengan menggabungkan beberapa foto sehingga menjadikannya satu frame foto. Dalam arti, dalam satu frame foto terdapat beberapa frame sebagai kolase seperti pada gambar 5 .

Angle, pencahayaan, dan atribut pendukung untuk pemotretan untuk menampilkan visual yang baik tentunya dasar-dasar dari pengambilan foto sudah termasuk dalam proses kreasi. Lalu ada pendekatan constructionist dalam metode fotografi potret dengan tema, ide dari model, atau mungkin juga objek fotonya [9]. Dengan pendekatan ini menjadikan suasana virtual photoshoot tidak menjadi kaku dan terkonsep yang akhirnya memudahkan proses pengambilan foto.

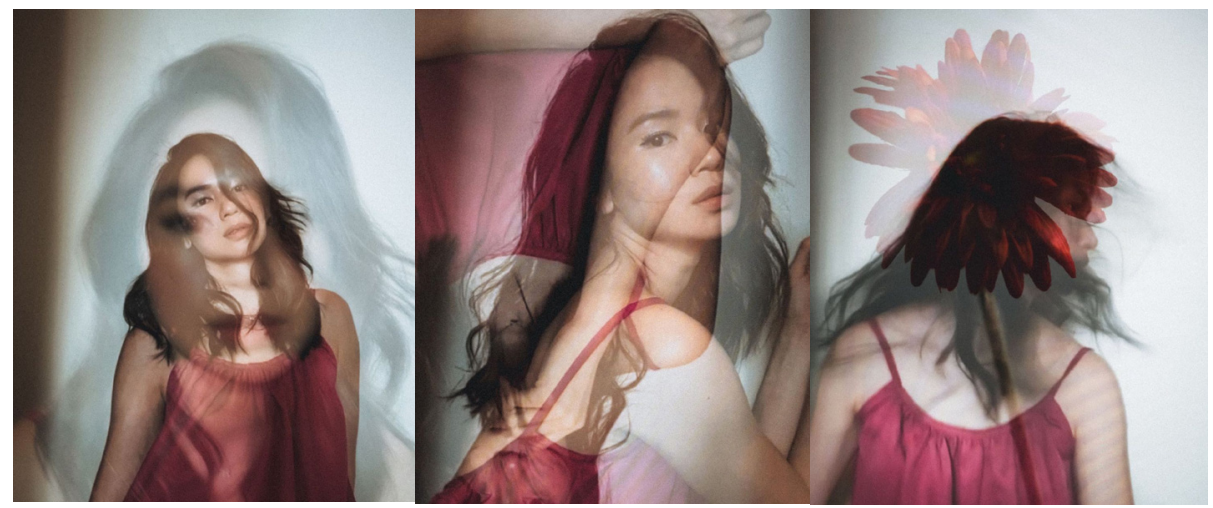

Gambar 5. Double Exposure pada pemotretan karya Laura Basuki (Sumber: Instagram @laurabas)

Teknik Close up dan full shoot digunakan sebagai teknik dalam pemotretan portrait karena umumnya foto portrait digunakan dalam pengambilan gambar dari atas kepala sampai bahu [10] menjadi angle yang banyak di gunakan dalam virtual photoshoot. Dengan bantuan teknik lainnya seperti blur, flare dan lain-lain untuk membantu membuat sebuah visual yang menarik dalam satu frame, arahan dari fotografer pun menjadi penting seperti sesi pemotretan biasa. Hanya yang membedakannya adalah komunikasi yang dilakukan secara virtual. Komposisi pun berperan penting dan untuk memposisikan POI (Point of Interest) sehingga menjadi lebih optimal dengan beberapa teknik seperti rule of third, framing, dan beberapa teknik lainnya.

\section{KESIMPULAN}

Virtual photoshoot mempunyai kemungkinan yang besar dalam perkembangan fotografi dan bisa menjadi awal sejarah dimulainya tren virtual photoshoot pada masa perkembangan fotografi. Biarpun, pada jaman dahulu terdapat pandemic seperti 1918 Spanish Flu Pandemic, tidak dapat menghasilkan tren yang sama diakibatkan karena berkurangnya teknologi seperti Skype, Facetime, Zoom, atau media video call lainnya. Dengan kombinasi teknologi baru dan kondisi yang terjadi, lahirlah perkembangan fotografi yang baru yaitu virtual photoshoot.

Secara media hasil menunjukkan bahwa dengan adanya media sosial seperti instagram dapat mendukung eksistensi tren virtual photoshoot. Secara teknis penelitian, metode pelaksanaan virtual photoshoot ini merupakan sesuatu yang baru dan belum pernah terjadi sebelumnya. Biarpun metode pelaksanaan virtual photoshoot ini sudah diterapkan dalam berbagai cara seperti in-game screenshoot dan Google Street View, virtual photoshoot menawarkan proses pemotretan dengan mengambil gambar melalui LCD monitor dengan menggunakan software video call seperti Zoom, Facetime, dan 
Google Meet untuk memunculkan objek foto. Secara estetika, penelitian ini menemukan bahwa hasil foto dari virtual photoshoot menimbulkan teknik fotografi yang belum banyak dipakai sebelumnya pada pemotretan konvensional, yaitu menampilkan efek blur pada foto menggunakan gelas atau botol. Efek blur yang biasa dihasilkan melalui pengaturan lensa ternyata dapat dihasilkan juga dengan gelas atau botol.

Virtual photoshoot merupakan era perkembangan "modern contemporary photography" yang lahir karena dampak COVID-19

\section{DAFTAR PUSTAKA}

[1]. S. I. Dewi dan F. Arbi, "Pengaruh Media Sosial Instagram Terhadap Minat Fotografi Pada Komunitas Fotografi Kamera Indonesia Malang," Jurnal IImu Sosial dan Ilmu Politik, vol. 6, no. 2, 2017.

[2]. WHO, "WHO Timeline - Covid-19," 27 April 2020. [Online]. Available: https://www.who.int/ news-room/detail/27-04-2020-who-timeline---covid-19.

[3]. M. Danah dan B. E. Nicole, "Social Network Sites: Definition, History, and Scholarship," Journal of Computer-Mediated Communication, vol. 13, no. 1, pp. 210-230, 2008.

[4]. S. Galuh A, "Instagram dan Gaya Hidup," 2017.

[5]. S. J. Kember, "The Virtual Life of Photography," Photographies, p. 176, 17 September 2008.

[6]. M. F. Cools, "Michael Cools Photography," [Online]. Available: https://www.instagram.com/ michaelcools/.

[7]. T. J. Seppala, “'Scape' mode in 'GT Sport' is basically Lightroom in a racing game," Engadget, 4 August 2017. [Online]. Available: https://www.engadget.com/2017-08-04-gt-sport-scape-mode.html.

[8]. ACP Photo Festival, "Street View Photography: from Doug Rickard through Jacqui Kenny," ACP, 26 October 2017. [Online]. Available: https://medium.com/@ACPfest/street-view-photography-fromdoug-rickard-through-jacqui-kenny-5eb9b7a42df9.

[9]. A. P. Gunawan, "Mendalami Dasar Dasar Dalam Pengambilan Pose Pada Pemotretan Model," HUMANIORA, vol. 4, no. 1, pp. 377-386, 2013.

[10]. S. M Irfan, D. Yudi dan R. , “Pemanfaatan Angle Fotografi pada Foto Dokumentasi," vol. 2, no. 1, February 2016. 